\title{
Stable isotope dating of historic buildings
}

D. Miles, ${ }^{a}$ N.J. Loader, ${ }^{b}$ G.H.F. Young, ${ }^{b}$ D. McCarroll, ${ }^{b}$ D. Davies, ${ }^{b}$ C. Bronk Ramsey, ${ }^{1}$ J.G. James ${ }^{\mathrm{b}}$

${ }^{a}$ Research Laboratory for Archaeology, Oxford University, 1 South Parks Road, Oxford, OX1 3QY, UK

${ }^{b}$ Department of Geography, Swansea University, Singleton Park, Swansea SA2 8PP, $U K$.

Corresponding Author: D. Miles (daniel.miles@arch.ox.ac.uk) Research Laboratory for Archaeology, Oxford University, 1 South Parks Road, Oxford, OX1 3QY, UK 


\section{Summary}

The recent development of an oxygen isotope $\left(\delta^{18} \mathrm{O}\right)$ master chronology for south central England (1200 - 2000CE) has successfully demonstrated reliable crossdating between the master chronology and undated samples from vernacular and high-status buildings. The method is well suited to invariant, wide-ringed samples, which are commonplace throughout the UK historic buildings archive and often fail to date by ring-width dendrochronology, or remain unsampled. This paper outlines briefly the isotope dating technique, and describes the application of the method to a number of case studies where ring-width dendrochronology has been unable to report a robust date. The close association between ring-width dating and stable-isotope dendrochronology is explored and its wider potential considered.

Keywords: dendrochronology, stable isotopes, oxygen, oak, beech, tree-ring

\section{Introduction}

Over the past four decades, dendrochronology has established itself as a reliable and routinely applicable method for dating timber artefacts, ranging from standing buildings and timber frames, to furniture and other art-historical artefacts. Although ring-width dendrochronology has proven extremely useful, the technique is not always able to return a conclusive date, for a number of reasons. Some ringwidth sequences are too invariant (complacent) or too disturbed (pollarded/managed) to carry a ring-width signal capable of being matched against regional master chronologies or individual dated samples. Samples may fall outside the geographic or temporal range of the reference chronologies available.

Occasionally the timber species sampled may not match that of those of available chronologies. Most commonly, the ring-width series are considered to contain too few rings to warrant sampling. For reliable ring-width dating of single series, in practice, it is rarely worthwhile examining single samples from a site unless they 
have more than 100 rings, although where timbers from the same structure can be grouped, dating $80-50$ rings may be possible. ${ }^{1}$

An alternative approach has recently been developed, dating tree-rings based upon their chemical composition. ${ }^{2}$ The technique analyses the differences in the relative proportion of naturally-occurring heavy and light forms (isotopes) of oxygen, carbon and hydrogen, that occur from year to year. These chemical signals are fixed into the cellulose of the tree ring and relate to the carbon dioxide and water assimilated by the tree during photosynthesis. Isotopic information is retrieved through a series of well-established laboratory procedures leading to the sample being converted to carbon monoxide (CO) or hydrogen $\left(\mathrm{H}_{2}\right)$ for stable isotope analysis using an isotope-ratio mass spectrometer. As the ratio of these isotopes is very small, for ease of communication, the isotope ratios are expressed as per mille (\%) deviations from a standard or reference value using the delta notation, e.g. $\delta^{18} \mathrm{O} .^{3}$

Stable isotopes in tree rings have been used extensively for the study of past climates, and the stable isotope ratios found for the carbon, oxygen and hydrogen isotopes typically demonstrate much stronger correlations between trees than is the case with ring widths. ${ }^{4}$ This is especially the case in the climatically temperate mid-latitude regions, such as the United Kingdom, where tree growth is not strongly constrained by a single climatic variable. Across the United Kingdom, the stable oxygen isotope ratios $\left(\delta^{18} \mathrm{O}\right)$ in latewood cellulose, used for dating, reflect the isotopic composition of the rainfall taken up by the tree during summer growth. ${ }^{5}$ As these chemical indicators carry a strong common environmental signal, dating between trees should be possible. Importantly, unlike conventional ringwidth dating, the oxygen isotope signal preserved within the cellulose of the tree 
rings is recorded passively; the trees do not need to be physiologically stressed to record this signal.

It has been suggested on several occasions that this common signal may allow stable isotopes to be used for cross-dating, in a similar manner to ring-width based dendrochronology. ${ }^{6}$ Our current research has clearly demonstrated that the stable oxygen isotope ratios from a master chronology containing as few as 10 oak trees, are capable of dating oak ring-width series across much of southern England and Wales. This includes samples that are too complacent, short or disturbed to be reliably dated using ring-widths alone. Isotope dendrochronology relies upon the same fundamental principles as conventional ring-width based dendrochronology. However, unlike the conventional procedure, which relies upon the measurement and matching of ring-widths, in isotope dendrochronology the physical ring-width measurements are replaced by the inter-annual differences in wood chemistry, in this case the stable oxygen isotope ratios measured from the latewood cellulose of individual timbers.

Isotope dendrochronology is a new and developing technique. Using a series of case studies this paper reports results obtained from both high-status and vernacular historic buildings, where isotope dendrochronology has been applied to support ring-width dendrochronology, or to independently date buildings for which ring-width dendrochronology has failed. A summary of all the dates so far obtained is also presented below in the first Stable Isotope Tree-ring Date List (VA, this volume, $\mathrm{pp} . \mathrm{xx}-\mathrm{xx})$.

\section{Methodology}

Development of the Master Chronology. 
A regional tree-ring $\delta^{18} \mathrm{O}$ master chronology was developed from dendrochronologically dated samples sourced from across the south-central England region (a c. $33,600 \mathrm{~km}^{2}$ area c. $51.488^{\circ} \mathrm{N},-1.035^{\circ} \mathrm{E}$ broadly centred on Oxford). Chronology development was conducted as part of a Leverhulme Trust project (RPG2014-327. This was a lengthy process, initially requiring access to many securely dated tree-ring samples. The majority of sample material used in this study was sourced from samples archived by the Oxford Dendrochronology Laboratory. The chronology currently covers the period from 1200 to 2000CE; replication (sample depth) is 10 trees throughout the chronology

\section{Sample preparation}

The core used for ring-width dendrochronology is mounted onto a wooden mount and a very fine slice removed and archived to preserve the top surface that was used for the original ring-width measurements. The remaining sample is then surfaced to a mirror finish, using a linisher and progressively finer grades of abrasive paper. For isotopic

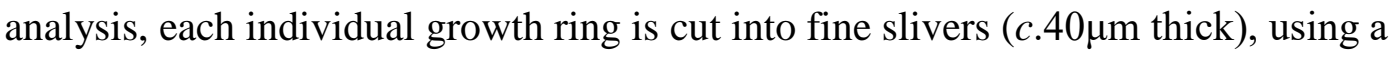
scalpel under magnification: carefully separating the latewood from the earlywood portion of each growth ring. The earlywood is preserved, but not used for isotopic analysis, as strong evidence indicates that, unlike the latewood, earlywood is formed in part using photosynthates stored from previous years and thus carries a signal from previous growing seasons. ${ }^{7}$ It is considered preferable to develop any isotope timeseries from individual trees, ${ }^{8}$ but resource constraints required us to develop our master chronology by combining and analysing the latewood from ten trees in two annuallyresolved "pools" comprising five-trees each. This enabled any processing errors to be detected and allowed us to test the homogeneity of the isotope signal across the region prior to the combination of the two pools into a single master chronology. 
The latewood for each pool is chemically processed to $\alpha$-cellulose, using standard methodologies, ${ }^{9}$ homogenised and freeze-dried; between 0.30 and $0.35 \mathrm{mg}$ of $\alpha$-cellulose is weighed into silver capsules for isotopic analysis. Each sample is pyrolised over glassy carbon at $1400^{\circ} \mathrm{C}$. Oxygen isotope ratios are measured on-line using a Flash HT elemental analyser interfaced with a Thermo Delta V isotope-ratio mass spectrometer, with analytical precision of $0.3 \% 0\left(\sigma_{\mathrm{n}-1} \mathrm{n}=10\right)$. Results are expressed as per mille (\%) deviations from the Vienna Standard Mean Ocean Water (VSMOW) standard. More detailed descriptions of the preparation, analysis and evaluation process can be found elsewhere. ${ }^{10}$ Individual samples for dating against the master isotope chronology were prepared following the same protocol.

\section{Cross-dating of Isotope Series}

Although the cross-dating procedure is broadly similar to that of ring-width dendrochronology, the statistical properties of the stable isotopic data are very different from those of ring-width sequences and so it is not appropriate to use the same statistical match criteria as routinely applied in conventional ring-width dendrochronology. ${ }^{11}$

The isotope data are nearly normally distributed and exhibit little skew, unlike ring-with data, which are far from normally distributed and are strongly skewed, due to growth trends. This means that ring-widths have high autocorrelation, which will enhance spurious matches. The ring-width data therefore need substantial pre-treatment to produce a normally distributed series suitable for correlation analysis. These statistical treatments, typically associated with the Baillie-Pilcher $t$ values, ${ }^{12}$ are not suitable for the isotope time series as they would potentially increase autocorrelation and produce spuriously inflated match statistics. ${ }^{13}$ For the isotopic data a simple indexing procedure (9-year rectangular filter with indices calculated by subtraction) is 
employed to remove the low frequency trends, which could inflate match statistics. Series are aligned sequentially against the master chronology, Pearson's $r$ - and Student's $t$-statistics are calculated to provide indications of the strength of the association for each year of the compared series. Corrections are made for autocorrelation and resampling (Bonferroni correction); unlike ring-width dendrochronology, the results permit a probability of a match to be assigned. The ratio of the highest to second highest probabilities are compared as a measure of uniqueness of match, the isolation factor (IF). ${ }^{14}$

To define potential matches, Loader et al. (2019) have proposed guideline thresholds for dating. ${ }^{15}$

1. The Bonferroni-corrected probability should be at least 1 in $100(1 / \mathrm{p} \geq$ 100)

2. The corrected probability for the strongest match should be at least an order of magnitude higher than that of the next highest value ("Isolation Factor" (IF) $\geq 10)$

These criteria are essentially the same as those proposed by Wigley et al. but applied more stringently; they used corrected probability of $1 / \mathrm{p} \geq 10$ and isolation factor $\geq 5 .{ }^{16}$ When a match passes these thresholds, it is not automatically accepted as a date, since fortuitously high correlation coefficients are not impossible and it is necessary to consider whether it is consistent with other evidence. ${ }^{17}$

Finally, the date assigned to the last isotopically measured ring must be placed in the context of the entire timber sample to obtain the felling date or range, taking into account any rings not measured isotopically and the presence or absence of sapwood, bark edge etc. following criteria identical to ring-width dendrochronology. ${ }^{18}$ 


\section{Results}

We present eight case studies where isotope dendrochronology has been used to date structures for which ring-width dendrochronology alone was not capable of providing a conclusive date. These examples provide an overview of the dating problems commonly encountered, where ring-width dendrochronology either failed entirely or yielded results not sufficiently conclusive to date a building or phase convincingly. For timbers dated isotopically, the type of sample, the final measured ring date, sapwood complement, the total number of rings $(\mathrm{N})$ and number of rings measured isotopically (Ni) are given (N/Ni). To interpret the strength, likelihood and uniqueness of the date, the Student's t-value, calculated probability of the date being correct $(1 / \mathrm{p})$ and degrees of freedom (df) corrected for resampling and autocorrelation are reported with the isolation factor (IF) providing a measure of uniqueness of match. The resulting isotope felling dates are then presented, taking into account the entire ring-width sample and noting its position in/relevance to the sampled building. ${ }^{19}$

\section{Maestorglwyd Barn, Llanigon, Breconshire (SO 2140 3742)}

(See Stable Isotope Tree-ring Date List Figures I-1 and I-2, p. хx.)

The former house at Maestorglwyd in Breconshire in south-east Wales is now a barn but was originally constructed as a medieval hall-house. It is a stone-walled and cruck-trussed hall-house of classic three-unit type, containing a two-bayed open hall, with a floored bay at the downhill end. The house was of gentry status, with an unusual trefoiled dais-end truss enhancing a recessed dais seat. The pointed arch-bracing at Maestorglwyd suggests an early date and it may be compared with the central truss at Llangwathen, a hall in the same late-medieval lordship of Hay, dated to 1418d. The site 
was discovered and first described by Jones and Smith; ${ }^{20}$ further details available on Coflein (RCAHMW's online database): NPRN 25890.

This site failed to date through conventional dendrochronological analysis, since most timbers were fast-grown with wide and invariant rings. Four samples were taken, but no satisfactory cross-matching was found between the individual sample sequences. The longest sequence (mmg13), with 98 rings, from the rear wall plate, was compared with the Oxford database of ring-width reference chronologies; a single, clearly defined and unambiguous date should produce a single high peak in BP-t-values for that year. If the values are scattered through time, then this reflects the absence of a unique wellreplicated match against the chronologies. It is important to note that whilst this test provides a useful indication of dating distribution, the individual chronologies in the database are not all independent of one another and the number of matches will reflect to some extent the degree of similarity between chronologies and the number and distribution of chronologies through time. The results for this test (Figure 1) fail to yield a conclusive date at any single dating position. Clearly, this sample could not be dated by conventional dendrochronology alone.

This sample was therefore selected for stable isotope dating. The measured ringwidth sequence had 98 rings, but the presence of heavily degraded sapwood and beetle frass meant that it was necessary to exclude the last 18 (sapwood) rings of the series, leaving 80 rings for isotopic analysis.

The strongest match returned for mmg13 oxygen isotope series against the oxygen isotope master chronology has a Student's $t$-value of 4.7 at $1393(\mathrm{r}=0.49$ overlap 80 years, 1/p=190 IF=401). By including the 18 rings not used for isotope analysis, the tentative dendro-date of 1411 is unambiguously confirmed and the later fifteenth century date which had no significant isotope match is ruled out (Figure 2). As 
this last ring was slightly crushed, the earliest possible felling date is winter 1411/12, but early in 1412 is more likely.

Given this new supporting information, two of the samples (mmg11 from a cruck blade, and mmg14 from a window lintel set in a stone wall), tentatively dated internally using ring-widths, could be matched with each other and against the now conclusively-dated mmg13. Sample mmg14 was ring-width dated (BP-t-value of 6.99) against CBMASQ01, confirming the final ring date of 1408. The mean of samples mmg13+mmg14 then matches with mmg11 giving a final ring date of 1391 . All of these statistically relatively weak ring-width matches are presented in Figure 3. The ringwidth measurements of all three samples were combined to form the site ring-width master MMGx2. The matches with the reference chronologies were considerably improved for a sequence of 1314-1411, with 3 results of BP- $t>6$ and thirteen results of BP- $t>5$, supporting the uniqueness of the fifteenth century date.

Using ring-width dendrochronology alone, the dating of Maestorglwyd would not have been possible. However, by the using stable isotope dating, a robust date was obtained which resolved ring-width dating ambiguities to support consistent intersample ring-width BP-t-values that yield a strong and secure ring-width date. This date is highly significant as it places Maestorglwyd as the oldest dated complete cruckframed hall-house in Wales, and within the top five oldest standing structures in the Principality.

2. Oldfields Farm, Moreton Say, Shropshire (SJ 629 364)

(See Stable Isotope Tree-ring Date List Figure I-3 p. xx.)

This is a complex farmhouse in North Shropshire, with a two-bay base-cruck hall at its core. This structure was sampled for the Shropshire Dendrochronology 
Project, but the hall failed to date using ring-width dendrochronology, although the later service end dated to late spring $1573 .{ }^{21}$ The upper parts of the base-cruck hall have as much as $8 \mathrm{~mm}$ of soot encrustation from the open fire, and an unusual squint in one of the centre struts. ${ }^{22}$

Two samples were taken from arcade posts from the base-cruck hall, of1 with 74 rings with complete sapwood to bark edge (winter felling), and of2 with 107 rings and incomplete sapwood; these two samples matched each other with a BP- $t=6.04$ at 56 years overlap. The second sample of2 was selected for isotopic analysis, as it had the longer ring sequence. However, only the first 100 rings were analysed, due to the sapwood being degraded. The oxygen isotope results matched with a Student's $t$-value of 7.10 against the master chronology, dating the last measured ring date to 1368. As the sample did not have bark edge, a precise felling date could not be established for it alone. However, combining the ring-width sequences of 2 and of1 gives a felling date of winter 1393/4. Thus, the precise date for the building, which has long defied conventional analysis, was established (Figure 4).

\section{The Vyne, Sherborne St John, Hampshire (SU 636 568)}

(See Stable Isotope Tree-ring Date List Figure I-4 p. xx.)

The Vyne, a large Tudor country house in Hampshire, was originally built in 1524-1526, but was substantially rebuilt in the 1650s by John Webb, a protégé of Inigo Jones. Whilst it has already been established the main south front was rebuilt using timbers felled in 1654, it was not possible to date the timbers of the portico using ringwidth dendrochronology. ${ }^{23}$ Two timbers taken from the main principal rafters of the portico (vyne11 and vyne12), both having bark edge and with 74 and 85 rings 
respectively, failed to date through dendrochronology, or even to match against each other.

Oxygen isotope ratios were therefore analysed for both timbers. Matching the isotope sequences against the master isotope chronology, established clear felling dates for both timbers of winter 1655/6 (vyne11 $t=6.42$ and vyne12 $t=5.84$ ). The two sequences also matched each other ( $r=0.74 n 73 p<0.0001$ ), even though the ring widths failed to match, and so the two timbers were combined to form a mean series. Matching this (vynex) against the isotope master chronology confirmed the felling date and improved the statistical match to an exceptional $t=7.47$ (Figure 5). The statistical match between the isotopes of these two timbers is so strong between that one might think they had originated from the same tree, yet from the ring-width data, this does not appear to be the case; presumably, rather, the trees grew under similar benign environmental conditions.

The felling dates of winter 1655/6 for both principal rafters coincide with documented building accounts of work to the south front and portico, between March 1655 to the end of 1656, making this portico the earliest on an English country house. ${ }^{24}$

\section{Lincoln College Chapel, Oxford (SP 514 063)}

The chapel range at Lincoln College was traditionally said to have been constructed between 1629 and $1630 .{ }^{25}$ It has been suggested that the roof used reused monastic timbers, due to the jointing details, including lap joists and halved dovetails and medieval-style carpentry assembly marks. Ten samples were taken from the roof timbers, of which nine timbers using ring-width dendrochronology dated, including six with bark edge. Three of these were felled in the spring of 1627, two in the spring of 1628, and one in the spring of 1629. One sample (linc3) failed to date, despite having a 
relatively long undisturbed ring sequence, so the latewood from a series of ninety-eight rings was analysed. The isotope data gave a clear and highly significant match with the master chronology of $t=8.7$ with a last measured ring date of 1626 (Figure 6). As the sample had bark edge and earlywood vessels visible, it was felled in the spring of 1627. The isotope dating establishes that the rafter is coeval with the rest of the seventeenth century work, and that none of the timbers were reused from the medieval period.

\section{Goosegreen Farmhouse, Yate, Gloucestershire (ST 7111 8377)}

(See Stable Isotope Tree-ring Date List Figure I-5 p. xx.)

This early seventeenth-century farmhouse is a stone-built twin façade-gabled building, with a solid-tread rear staircase turret (incorporated in a later extension). It contains rare and well-preserved examples of vernacular wall painting, comprising remarkable and colourful faux panelling. These paintings were stylistically dated to the late sixteenth or early seventeenth centuries. ${ }^{26}$

In 2014 five timbers were sampled, three from the main range roof, and two from the solid-tread staircase tower, all with between 64 and 93 rings. Most timbers in the house were fast-grown, with little sapwood, and the timbers which were sampled had some bands of narrow or distressed rings. It was therefore not surprising that ringwidth dendrochronology failed to produce any clear dates.

Sample ggfh3, a purlin from the main range roof, was considered the most suitable for isotope analysis. It had 64 rings including about 16(C?) of sapwood. The last rings in the sapwood (before the bark edge) were fragmentary. Six sapwood rings were measured; it is, however, possible that it had an extra ring, giving 65 rings total (ggfh3). Unfortunately, it is hard to be conclusive with such a small and fragmentary amount of material. 
The oxygen isotope measurements of a single sample ggfh3, using 52 rings, give a single clear match for the final measured ring of $1592(\mathrm{r}=0.77, t=7.68,1 / \mathrm{p}>1$ million, IF > 1000). This allowed a felling date of winter circa 1607/8 to be determined. As the wall paintings appear to be contemporary with the building, this date can be assigned to them as well (Figure 7).

6. Cruck Cottage’'4 Old School Lane, Wilmcote, Warwickshire (SP 164 579) (See Stable Isotope Tree-ring Date List Figure I-6 p. xx.)

This house is a complex structure, now in multiple ownership, and comprises nos. 2, 4 and 6 Old School Lane (Harpe Cottage, Cruck Cottage and Lane End Cottage), with a cross-wing, Kirkside. The first three each occupy a single bay of the original medieval cruck hall house, with nos 2 and 4 making up the former open hall; no. 6 was the service bay at the east end. An unusual feature of the house is the spere truss, which is of aisled form, similar to an example from Skirmett in Buckinghamshire dating to $1444-74 .^{27}$

Five samples were taken from this complex by Dr Martin Bridge in April 2017. Three were from the later cross wing dated to 1522-55 (VA 48, 115), and two from the open cruck hall at 4 Old School Lane (Cruck Cottage) which failed to date. It was decided to examine the longer of these two samples (wilm04) isotopically. After omitting the first few rings which had growth distortions, a 62-ring isotope sequence was obtained, which ran up to the last full ring at the bark edge. This gave a single clear match against the master isotope reference chronology, with the final ring at 1371 (Figure 8). As there was an unsampled partial ring following this, a precise felling date of spring or summer 1372 can be established; this final ring was abraded, so the exact season is uncertain. 
The ring-width sequence did give matches with some master chronologies at 1371, but these matches were far too weak to provide a firm date. The isotope dating technique however, succeeded and Wilmcote has now been shown to be the earliest dated full-cruck house in Warwickshire. ${ }^{28}$ Particularly significant is the dating of the spere truss, to almost a century earlier than the only other previously known parallel; these two, taken together are of considerable importance in our understanding of the planning and use of medieval cruck houses.

\section{Loxley Farm, Loxley, Warwickshire (SP 256 530)}

(See Stable Isotope Tree-ring Date List Figure I-7 p. xx.)

This cruck house was originally sampled, by Robert Howard, in October 1988, for the Leverhulme Trust supported Medieval Peasant House Project. ${ }^{29}$ The house retains the four trusses of the open hall and kitchen, all heavily smoke-blackened. Despite ten samples being taken, none proved possible to date using ring-widths. In a second attempt to date this house, five more samples were taken in October 2018 by Dr Martin Bridge, of the Oxford Dendrochronology Laboratory, but again these samples failed to date by ring-width dendrochronology. ${ }^{30}$

Two of the second set of samples were analysed isotopically and were found to match independently with the master chronology, loxb03 dating to 1419 and loxb05 dating to 1414. The two samples also matched very well with one another, at a five-year offset $(r=0.697 n=62)$. The combination of the two sequences into a single mean series (loxx) gives improved matches with the oxygen master chronology (Figure 9). $(\mathrm{t}=6.63$, 1/p >200,000, Isolation Factor >1000). Sample loxb-05 had 20 sapwood rings, very distorted, but incomplete. Therefore, with a last measured ring date of 1414, a felling date range of 1415-35 was determined. Sample loxb-03 had 12C complete sapwood to 
the bark edge, giving a last measured ring date of 1419, and a felling date of winter $1419 / 20$. This date is somewhat earlier than expected making it amongst the earliest Warwickshire cruck houses. ${ }^{31}$

\section{Future Potential and Wider Application:}

Non-oak species:

Oak dominates historic buildings across England and Wales, but other species such as elm, beech, chestnut, and pine occur sporadically, especially in vernacular buildings. No long reference chronologies have been compiled for these species in England and Wales, although some chronologies exist for pine, primarily from Scotland and Ireland. Hence, a conventional approach to ring-width dating of these species is difficult at best, and often impossible.

As the oxygen isotope signal in oak trees is driven by the precipitation used by the tree during photosynthesis and growth, it is likely that other tree species growing in the same area, sampling the same water and sharing phenology and structure, will carry a similar potentially dateable signal. A very exciting result from the perspective of vernacular architecture has been obtained for our eighth site, through the application of the stable isotope dating technique to a sample of beech (Fagus spp.) from an in situ mantel beam at Well Cottage, Tinkers Green, Mapledurham, Oxfordshire. Despite having only 60 rings and beech being a diffuse porous species not frequently encountered and not generally datable using oak chronologies. This sample had bark preserved, allowing a precise felling date of winter 1804/5 to be determined (See Stable Isotope Tree-ring Date List Figure I-8 p. xx.)).

Significant potential exists for further investigation into the use and age of nonoak timbers within UK historic buildings and work is already underway to explore the 
nature of the isotopic signal as preserved in elm, pine, and chestnut. This work will not only explore the potential for isotope dating of non-oak timbers, but also the potential of the technique to support construction of regional elm (and other non-oak) tree-ring width chronologies.

\section{Geographic Range}

Although our reference chronology centres on Oxford in south-central England, we have been successful in dating individual timbers and chronologies from as far afield as Northern Ireland (Portaferry Co. Down (Stable Isotope Tree-ring Dates, List 1, this volume) and west Wales (Llanarthne) (unpublished data). The geographic dating range of the existing isotope chronology appears, from this limited research, to be far wider than that of ring widths, and broadly follows the climatic 'footprint' of the mainly south-westerly air masses providing precipitation across central England. ${ }^{32}$ This signal weakens towards the north, west and southwest, suggesting that further regional chronologies will be required to provide more specific dating evidence for northern England, Scotland, west Wales and south-west England.

\section{Sequence Length}

One of the most promising aspects of this method is the potential to date tree ring sequences that are too short for reliable conventional ring-width dendrochronology, which usually requires greater than 50 rings and ideally more than 100 . Re-analysis of the dated timbers, used to evaluate the method, by selecting only the first (earliest) 50 rings, shows that each truncated 50-ring sample segment dates well. The set of $>9000 t$ values given by false matches also allows us to confirm that the results closely follow the $t$-distribution. Importantly, they show no increase in the occurrence or magnitude of 
false or spuriously high matches as segment length is reduced. Work is continuing to explore the lower limits of the technique, but the results to date are very encouraging.

\section{Conclusions}

Dendrochronology is the most accurate and precise scientific dating method currently available, able to provide information with annual and sometimes seasonal resolution. Isotope-dendrochronology is equally precise. The examples presented here and elsewhere show that oxygen isotopes from oak carry a stronger common signal than ring-widths in the UK. ${ }^{33}$ Oxygen isotope variability has been shown to be capable of dating across a wider geographical area than ring widths and of dating short, complacent and disturbed ring sequences. As for ring-width dendrochronology, ideally more than one sample from a phase of building should be analysed, as we have demonstrated in some of the case studies above. Similarly, where trees are exceptionally slow growing or disturbed and lay down only early wood, the development of a sufficiently long latewood isotope record may not be possible.

Dendrochronology has been revolutionising the study of historic architecture and timber framing for decades. Through provision of precise chronology, tree-ring dating has been able to resolve many historical questions. However, mysteries remain which ring-width dendrochronology has not been able to resolve. In many instances, radiocarbon dating has been used to provide dates where ring-widths have failed, although it lacks the perfect resolution afforded by dendrochronology. Stable isotope dendrochronology has now joined the suite of tools available to date wooden structures and artefacts and fills a gap between these two techniques.

While stable isotope dendrochronology offers distinct advantages in dating short, invariant and non-oak sequences, and fills a dating "gap” between ring-width 
dendrochronology and radiocarbon dating, these analyses are relatively costly and timeconsuming to undertake. They are therefore unlikely to replace conventional ring-width dating, where timbers are suitable for traditional dendrochronology, so the method has so far been applied following the failure of conventional dendrochronology. Ring-width measurement and analysis is also essential, as demonstrated here, if the isotope date is to be placed within the context of the sample assemblage. Furthermore, and in common with ring-width dendrochronology, a felling date can only be given when bark edge is present and a felling date range when some sapwood is preserved. ${ }^{34}$

Isotope dating is a significant advance in scientific dating and dendrochronology. Additional chronologies will undoubtedly be required to widen the range and scope of the method. The method is not limited to the United Kingdom and could easily be expanded into other regions. It is hoped that similar research across the United Kingdom, Europe, New Zealand and the north-eastern United States will help to shine light on other problematic tree-ring samples and on relatively unexplored regions.

Acknowledgements: The authors thank The Landmark Trust, The National Trust, Caroline Stanford, Richard Burton, Ross Cook, Nat Alcock, Martin Bridge, David Brown, Richard Suggett for their support and assistance in developing the technique and the provision of samples for this study, and we thank the Leverhulme Trust (RPG-2014327) and UK NERC (NE/P011527/1) for grant support.

Notes:

Bibliography:

Alcock, N.W. 2017. “The scientific dating of standing buildings.” Science Progress. 100 (2017):374-399. 
Alcock, N.W. and Miles, D. “The Medieval Peasant House in Midland England.” Oxbow books, Oxford. 326pp. 2013.

Baillie, M.G.L. and Pilcher, J.R. “A simple cross-dating program for tree ring research.” Tree Ring Bulletin 33 (1973):7-14.

Bayliss, A., Marshall, P., Tyers, C., Bronk Ramsey, C., Cook, G., Freeman, S. and Griffiths, S. “Informing conservation: towards C-14 wiggle-matching of short tree ring sequences from medieval buildings in England.” Radiocarbon 59 (2017):985-1007.

Bridge, M. Oxford Dendrochronology Laboratory report 2017/24. (2017 unpublished).

Coplen, T.B. “Discontinuance of SMOW and PDB” Nature 375 (1995):285.

Hill, S.A., Waterhouse, J.S., Field, E.M., Switsur, V.R., ap Rees, T. “Rapid recycling of triose phosphates in oak stem tissue” Plant, Cell \& Environment 18 (1995):931936. doi:10.1111/j.1365-3040.1995.tb00603.x

Historic England (formerly English Heritage) "Dendrochronology: guidelines on producing and interpreting dendrochronological dates” English Heritage, London. 1998.

Hollstein, E. “Mitteleuropäische Eichenchronologie Trier dendrochronologische Forschungen zur Archäologie und Kunstgeschichte” Trierer Grabungen und Forschungen 11 (1980): 273pp.

Jones, S. and Smith, J. “Brycheiniog” X 118-23. 1964. 
Leavitt, S., Long, A. and Dean, J., “Tree-ring dating through pattern-matching of stablecarbon isotope time series” Tree Ring Bulletin 45 (1985):1-10.

Loader N.J. and Switsur, V.R. "Reconstructing past environmental change using stable isotopes in tree-rings” Botanical Journal of Scotland 48 (1996):65-78.

Loader, N.J., McCarroll, D., Miles, D., Giles H.F. Young, G.H.F., Davies, D., and Bronk Ramsey, C. "Tree Ring Dating Using Oxygen Isotopes: A Master Chronology for Central England" Journal of Quaternary Science. (2019) DOI: 10.1002/jqs.3115

Loader, N.J., Robertson, I., Barker, A.C., Switsur, V.R., and Waterhouse, J.S. “An improved technique for the batch processing of small wholewood samples to $\alpha$ cellulose” Chemical Geology 136 (1997):313-317.

Loader, N.J., Young, G.H.F., Grudd, H., and McCarroll, D. “Stable carbon isotopes from Torneträsk, northern Sweden provide a millennial length reconstruction of summer sunshine and its relationship to Arctic circulation” Quaternary Science Reviews 62 (2013):97-113.

McCarroll, D. and Loader, N.J. "Stable isotopes in tree rings” Quaternary Science Reviews 23 (2004):771-801.

McCarroll, D. and F. Pawellek. "Stable carbon isotope ratios of Pinus sylvestris from northern Finland and the potential for extracting a climate signal from long Fennoscandian chronologies” Holocene 11 (2001):517-526.

McCarroll, D., Whitney, M., Young, G.H.F., Loader, N.J. and Gagen, M. “A simple stable carbon isotope method for investigating changes in the use of recent versus old carbon in oak” Tree Physiology 37 (2017):1021-1027. 
Miles, D.H. "Refinements in the Interpretation of Tree-Ring Dates for Oak Building Timbers in England and Wales.” Vernacular Architecture 37 (2006):84-96.

Miles, D. and Bridge, M. “Tree ring dating lists from the Oxford Dendrochronology Laboratory - List 295” Vernacular Architecture 48 (2017).

Miles, D.H. and Haddon-Reece, D. "Tree ring dating lists from the Oxford Dendrochronology Laboratory - List 56” Vernacular Architecture 25 (1994).

Miles, D.H. and Worthington, M.J. "Tree ring dating lists from the Oxford Dendrochronology Laboratory - Lists 90-94” Vernacular Architecture 29 (1998).

Moran, M. Vernacular Buildings of Shropshire (Oldfields Farm, Moreton Say). Logaston Press, pp 462-4 2003.

Robertson, I., Switsur, V.R., Carter, A.H.C., et al. "Signal strength and climate relationships in ${ }^{13} \mathrm{C} /{ }^{12} \mathrm{C}$ ratios of tree ring cellulose from oak in east England”, Journal of Geophysical Research 102 (1997):19507-19519.

Saurer, M., Cherubini, P., Reynolds-Henne, C.E., Treydte, K.S., Anderson, W.T., and Siegwolf, R.T.W. “An investigation of the common signal in tree ring stable isotope chronologies at temperate sites” Journal of Geophysical ResearchBiogeosciences 113 (2008):G04035.

Switsur, V.R., Waterhouse, J.S., Field, E.M., Carter, A.H.C., Loader, N.J. "Stable isotope studies in tree rings from oak - techniques and some preliminary results” Paläoklimaforschung 15 (1995):129-140. 
Treydte, K., Frank, D., Esper, J., Andreu, L., Bednarz, Z., Berninger, F., Boettger, T., D'Alessandro, C.M., Etien, N., Filot, M., Grabner, M., Guillemin, M.T., Gutierrez, E., Haupt, M., Helle, G., Hilasvuori, E., Jungner, H., Kalela-Brundin, M., Krapiec, M., Leuenberger, M., Loader, N.J., Masson-Delmotte, V., Pazdur, A., Pawelczyk, S., Pierre, M., Planells, O., Pukiene, R., Reynolds-Henne, C.E., Rinne, K.T., Saracino, A., Saurer, M., Sonninen, E., Stievenard, M., Switsur, V.R., Szczepanek, M., Szychowska-Krapiec, E., Todaro, L., Waterhouse, J.S., . Weigl, M., and Schleser, G.H. "Signal strength and climate calibration of a European tree ring isotope network” Geophysical Research Letters. 34 (2007): L24302.

Wigley, T.M.L., Jones, P.D. and Briffa, K.R. "Cross-dating methods in dendrochronology” Journal of Archaeological Science 14 (1987):51-64.

Young, G.H.F., Loader, N.J., McCarroll, D., Bale, R.J., Demmler, J.C., Miles, D., Nayling, N.T., Rinne, K.T., Robertson, I., Watts, C., Whitney, M. “Oxygen stable isotope ratios from British oak tree rings provide a strong and consistent record of past changes in summer rainfall” Climate Dynamics 45 (2015):3609-3622.

${ }^{1}$ (a) Loader et al. (2019) developed and applied the stable isotope dating technique for the UK. A detailed account of the chronology building process and development of the statistical approach to dating are provided in this reference. (b) Alcock, N.W. "The scientific dating of standing buildings.” 374-399. (c) Bayliss, A., et al. "Informing conservation: towards C-14 wiggle-matching of short tree ring sequences from medieval buildings in England.”

2 Loader, N.J., McCarroll, D., "Tree Ring Dating Using Oxygen Isotopes: A Master Chronology for Central England". 
3 Coplen, T.B. "Discontinuance of SMOW and PDB”.

4 (a) McCarroll, D. and Loader, N.J. "Stable isotopes in tree rings"; (b) Treydte, K., et al. "Signal strength and climate calibration of a European tree ring isotope network"; (c) Saurer, M., et al. "An investigation of the common signal in tree ring stable isotope chronologies at temperate sites"; Robertson, I., et al. "Signal strength and climate relationships in ${ }^{13} \mathrm{C} /{ }^{12} \mathrm{C}$ ratios of tree ring cellulose from oak in east England”.

5 Young, G.H.F., et al. “Oxygen stable isotope ratios from British oak tree rings provide a strong and consistent record of past changes in summer rainfall”.

6 See note 1(a); Leavitt, S. et al. "Tree-ring dating through pattern-matching of stable-carbon isotope time series”; Loader N.J. and Switsur, V.R. "Reconstructing past environmental change using stable isotopes in tree-rings”.

7 Switsur, V.R., et al. "Stable isotope studies in tree rings from oak - techniques and some preliminary results"; Hill, S.A., et al. "Rapid recycling of triose phosphates in oak stem tissue”; McCarroll, D., et al. “A simple stable carbon isotope method for investigating changes in the use of recent versus old carbon in oak”.

8 Loader, N.J., et al. "Stable carbon isotopes from Torneträsk, northern Sweden provide a millennial length reconstruction of summer sunshine and its relationship to Arctic circulation”.

9 Loader, N.J., et al. "An improved technique for the batch processing of small wholewood samples to $\alpha$-cellulose”.

10 See notes 2 and 4(a).

11 (a) Baillie, M.G.L. and Pilcher, J.R. “A simple cross-dating program for tree ring research”;

(b) Hollstein, E. "Mitteleuropäische Eichenchronologie Trier dendrochronologische Forschungen zur Archäologie und Kunstgeschichte”; (c) Historic England (formerly English Heritage) “Dendrochronology: guidelines on producing and interpreting dendrochronological dates” English Heritage, London. 1998.

12 See note 11(a) 
13 See note 2; The isotope dating technique uses the Student's $t$ value. The Baillie-Pilcher $t$ value should not be used with stable isotope data owing to differences in the statistical distribution of the data that can inflate the strength of the match between the series.

14 Wigley, T.M.L., et al. "Cross-dating methods in dendrochronology".

15 See note 2.

16 See note 14.

17 The stepwise nature of tree ring dating (both ring-width and isotopes) mean that there is a statistical probability that a match may occur in error by chance. In ring-width dendrochronology, this cannot be quantified due to the statistical distribution and treatments applied to the ring-width data. This is often overlooked by practitioners and end-users who have misrepresented or misinterpreted dendrochronology as a dating method without uncertainty. Stable isotope dating also experiences the same statistical uncertainties, but the near-normal distribution of the data and adjustments made for resampling and autocorrelation mean that it is possible to provide with every date a match probability, calculated for a specific comparison of sample and reference chronologies. When a match passes these thresholds, it is not automatically accepted as a date. Fortuitously high correlation coefficients are not impossible, and it may be necessary to consider other lines of evidence that are available to the practitioner. For isotope dating, statistically these should only occur in less than $1 \%$ of cases, according to the criteria applied.

18 See note 11(c); Miles, D.H. "Refinements in the Interpretation of Tree-Ring Dates for Oak Building Timbers in England and Wales.” Vernacular Architecture 37.

19 As note 18.

20 Jones, S. and Smith, J. “Brycheiniog” X 118-23. 1964.

${ }^{21}$ Miles, D.H. and Haddon-Reece, D. "Tree ring dating lists from the Oxford Dendrochronology Laboratory - List 56” Vernacular Architecture 25.

22 Moran, M. Vernacular Buildings of Shropshire (under Oldfields Farm, Moreton Say).

${ }^{23}$ Miles, D.H. and Worthington, M.J. “Tree ring dating lists from the Oxford Dendrochronology Laboratory - Lists 90-94” Vernacular Architecture 29. 
24 See note 2.

25 Miles, D. and Bridge, M. “Tree ring dating lists from the Oxford Dendrochronology Laboratory - List 295” Vernacular Architecture 48.

26 Andrea Kirkham (personal communication).

27 Alcock, N.W. and Miles, D. "The Medieval Peasant House in Midland England.” (SKI-A).

28 Nat Alcock (personal communication).

29 Alcock, N.W. and Miles, D. “The Medieval Peasant House in Midland England.” (LOX-A).

30 Bridge, M. Oxford Dendrochronology Laboratory report 2017/24. (2017 unpublished).

31 Nat Alcock (personal communication).

32 See note 5.

33 See notes 2 and 5.

34 See note $11(\mathrm{c})$. 